\title{
BUILDING RESILIENCE FOR A FLOURISHING WORLD
}

\author{
JAMES A. F. STONER \\ Gabelli School of Business \\ Fordham University \\ New York, New York, U.S.A. \\ stoner@fordham.edu
}

On June 9, 2009, the IAJBS's $15^{\text {th }}$ Annual World Forum passed a resolution that was very unusual, perhaps even unique, for any set of annual conferences. The theme of the 2009 World Forum at XLRI in Jamshedpur, Jharkhand, India, was "Leadership for Sustainability." The Jamshedpur resolution called for the next ten years of World Forums to be dedicated to the theme of global sustainability. All the World Forums since then have been built around this theme, focusing on topics such as "Educating champions of sustainable development: Best practices of our business schools," "Technology and business for a sustainable world," and "Sustainability \& business practices: Implications for our schools."

The idea of establishing an IAJBS journal focusing on global sustainability emerged the following year at the end of the 2010 World Forum at Ateneo de Manila University. The resulting Journal of Management for Global Sustainability published four articles and an essay addressing the need to take action on the many inter-related aspects of global unsustainability, its disproportionate impacts on the world's most vulnerable peoples-most notably its impacts on increasing and making more intractable the tragedies of poverty and social injustice-and, of course, threats to the very existence of all species, including our own.

In June of 2009, the atmospheric $\mathrm{CO}_{2}$ level was reported to be 389 ppm, having passed, in April 1987, the level of 350 ppm, widely recognized to be the point at which further increases in $\mathrm{CO}_{2}$ levels seemed very, very likely to start a series of complex and destructive changes in the world's climate. On August 15, 2017, the Mauna Loa Observatory (NOAA-ESRL) reported $\mathrm{CO}_{2}$ atmospheric concentration to be 405 ppm (ProOxygen, 2017). As the world continues to fail to take adequate actions to avoid global warming and climate change, the 
predictions of severe consequences continue to turn out to be tragically accurate and apparent. Impacts of climate change and global warming seem to be visible virtually every day and seemingly everywhere (even on this $28^{\text {th }}$ of July, shortly after the 2017 World Forum at Namur University, when one is on vacation near the French village of Les Eyzies and listens to the saddened words of highly-respected truffle farmer Eduard Aynaud as he describes the unfortunate and escalating changes in his own farm and community).

As the myriad and seemingly unending impacts of global unsustainability have accumulated, awareness of the need to develop new and more effective efforts to reduce and eventually end its contributing factors has increased. Acknowledging the need to keep building personal, organizational, community, and worldwide resilience to respond to, and hopefully contribute to the removal of, the conditions that create these impacts is therefore part of this awareness. Recognizing that the term flourishing (Ehrenfeld, 2010; Ehrenfeld \& Hoffman, 2013; Laszlo \& Brown, 2014) is an attractive phrasing to capture and perhaps go beyond the word "sustainability," the articles in this issue of the JMGS are in the spirit of building resilience thinking and actions (Walker \& Salt, 2006) at all levels and in all ways to create a flourishing world.

There are many ways to frame not only the problem of global unsustainability but also possible approaches to creating greater resilience for dealing with our unsustainability-related problems. For instance, one of the deeper ways of looking at the problem of unsustainability, and of seeking opportunities for increasing resilience, is to see unsustainability as a spiritual concern. Not only do the ways we produce, distribute, and consume leave many of the world's people with little or no ability to meet the barest minimum of human needs, but even many of the most privileged of us are alienated from our natural and inherent connection with deeper meaning in life and work. Consumerism is turning out to be a pretty hollow and unsatisfying new religion. Many of our organizations seem to be committed only to financial gain for a limited number of "shareholders" or, perhaps more accurately, for the increasingly shortterm oriented speculators in a company's shares. And, of course, the ways we produce-distribute-consume are destroying the capacity of the planet to support our existence as well as that of many other species.

Pope Francis' words in Laudato Si'-built as they are on the counsel, research, scholarship, and wisdom of many of the wisest experts in the world-have called attention to the need for changes not just in what we do but also in our ways of being in the world-who we "are." Laudato Si' can thus be seen as a call for transformative individual and institutional 
leadership that is grounded in our deepest and most spiritual ways of being. It is such an important document that it, in addition to being the focus of the first article in this issue, will serve as the theme of the next.

In this sense, new leadership that is transformed and transformative is increasingly needed and called for at all levels and in all places. The first two articles in this issue, then, emphasize the importance of such leadership in building resilience. In both, the reality of the spiritual nature of the global unsustainability problem is evident, as is the need for leadership grounded in the best of our ways of being, in our spiritual nature.

In "Laudato Si' and a spirituality of resiliency," Robert Brancatelli reminds us of the spiritual nature of the global unsustainability problems and the opportunities for seeking spiritually-aware ways of being in our efforts to solve those problems. Focusing on business leaders and how they "might prepare for resiliency individually and then lead" their organization through the crisis of "environmental deterioration," Brancatelli frames his discussion in the "perspective of a spirituality of presence," explores the two dimensions of this spirituality: the prophetic and the contemplative, and "demonstrates their application in a business context," noting that "an important part of a spirituality of presence is Sabbath, which allows for the rest and re-centering of the individual and organization. Once 'frenetic activity' ceases, both the leader and the organization can begin the work of anticipating, preparing for, and responding to crises."

Building on many years of work in such fields as corporate social responsibility, global sustainability, organizational transformation, and, more recently, the nature and leadership of "intellectual shamans," Sandra Waddock discusses the need to develop the kinds of transformative leaders that can see beyond the "frenetic activity" noted by Brancatelli. Recognizing and honoring the spirituality-inspired wisdom of the world's great shamanic traditions, Waddock describes the need and opportunities for shamanic-inspired leadership very clearly in her article, "Leaders as shamans: Working to heal a troubled world":

In a world greatly in need of healing, today's leaders acting as shamans could potentially bring the shaman's ancient wisdom to the effort to create a more sustainable, just, and equitable world. Today's shamanic leaders undertake the same roles as the traditional shaman: healing, connecting, and sensemaking in the service of a better world. From a leadership perspective, the shaman's work is that of healing the world around us and our (human) relationship with that world, which is what many leaders 


\begin{abstract}
are already attempting to do. In this context, healing can mean making our relationships, systems, and organizations whole or sound. In a similar vein, connecting means working across boundaries of different types, such as relationships, disciplines, functions, sectors, and institutions, among others, to create collaborative initiatives or new insights that can move ideas and institutions forward in a positive way. Finally, sensemaking means helping others understand and interpret their world in new and hopefully constructive ways. It means creating a new vision of the future through tasks like developing new memes or framing new stories or narratives that help people relate to their enterprises or the world in different ways. In today's troubled world, where our dominant cultural mythologies, policies, and practices have resulted in frighteningly unsustainable conditions and divisiveness, [she argues] that more leaders explicitly need to (and can) take on these shamanic roles.
\end{abstract}

These calls for new leadership can be seen in turn as calls for creating educational innovations that will enable and support the emergence of the kinds of leadership and actions that help create a flourishing world. Indeed, Laudato $\mathrm{Si}^{\prime}$ is a call for fresh and committed leadership in the Jesuit tradition of men and women with and for others.

The article by Marco Tavanti et al. and the essay by Elmer Soriano continue to contribute to our thinking about leadership for resilience. They do so by focusing on educational opportunities for developing individuals who are committed to creating a flourishing world and are active in bringing that world into being. In "Management education for sustainable development: Integrating ecology and community values in social impact practicums," Marco Tavanti, Molly Brennan, and Shelly Helgeson discuss the innovations in education being developed and pioneered at San Francisco University. With a focus on integrating university course work and social contributions from community-based, action-learning projects, they explore "a management education model to help integrate sustainable development ideas into university curricula and programs. This pedagogical model emphasizes a community-based approach along with other proven methods for university-community collaborations and course-based social impact analysis."

The authors explore the concept of integral ecology as it appears in Laudato Si' and how educating for sustainable development can start with community capacity development. Their article describes how the

Laudato Si' encyclical's notion of integral ecology, along with the need to create community-benefit academic programs, inspired the establishment of a partnership between the University of San Francisco's Master of Nonprofit 
Administration program and the Foundation for Sustainability Development. This partnership experience expanded into development practicum courses and solidified into strategies for integrating experiential learning and organizational development through community-based analysis.

They feel that the "graduate level pedagogical models discussed [in their article] are relevant to other academic institutions and programs that would like to educate students with a community-centered approach." They believe their work suggests that both sustainability and resilience cannot be articulated in educational and capacity development settings without intentionally and methodologically providing tools for building social capacity.

In "Moderating the impact of climate change one university at a time," Elmer S. Soriano describes how Typhoon Haiyan led to the development of a powerful and transformative action-learning experience with the students in his class during and right after it passed through the Philippines. Building on the learning he and his students experienced from the social contribution projects that emerged from that class and others, he expands the concept of classroom-created social action projects to the global level by suggesting that responding to "the threats posed by climate change presents a leadership challenge proportional in scale with the urgency and complexity of wartime mobilization." He describes how the "world's 190 million students may be enlisted to respond to such threats through action-research focused on building resiliency."

Looking toward the possibility of bringing about the kinds of transformative educational leadership needed to meet the challenges of climate change and global unsustainability, Soriano argues that concepts "such as social labs, institutional empathy, and scholarship [can] help reframe the mandates of universities as they respond to climate change, making them platforms for developing leaders and changemakers who will increase the resilience of communities and ecosystems."

In "Building urban water resilience: New perspectives for the Guadalajara drought-readiness program," Rodrigo Flores-Elizondo describes some of the challenges and complexities inherent in large-scale projects to build community resilience for a critically important resource: water. He notes that climate change "is compelling cities to become resilient in the face of a wider range of meteorological phenomena. Starting with approaches to cope with hurricanes or floods, resilient city strategies have to consider longer-term and more territorially expansive challenges, such as multi-annual and multi-regional droughts." 
He says that

[u]rban planners, local and regional governments, and political consultants are therefore driven to consider more complex models to build resilient cities. One example is the case of Guadalajara, Jalisco, Mexico's second largest city and which was recently included in the 100 Resilient Cities network. The city obtained a drought management program from the federal government in 2015, but such efforts have not yet been coordinated with current public policy or with the rapid growth of the city.

In response to these challenges, Flores-Elizondo outlines "a more comprehensive proposal of public policy to deal with a big city's water supply and expected shortages."

In a sense, Flores-Elizondo's article brings this issue of the JMGS full-circle with his description of what needs to be done to move toward an effective large-scale resiliency project. Projects on the scale and with the complexity he describes seem to require the types of inspired and transformative leadership-on many, many levels and in many collaborating entities-described in the other articles and the essay in this issue. And creating such new leadership seems to call in turn for the supporting educational system innovations described and suggested therein.

\section{REFERENCES}

Ehrenfeld, J. R. 2010. Sustainability by design: A subversive strategy for transforming our consumer culture. New Haven: Yale University Press.

Ehrenfeld, J. R., \& Hoffman, A. J. 2013. Flourishing: A frank conversation about sustainability. Stanford: Stanford University Press.

Laszlo, C., \& Brown, J. 2014. Flourishing enterprise: The new spirit of business. Stanford: Stanford Business Books.

ProOxygen. 2017. CO2 earth: Are we stabilizing yet? Available at https://www.co2. earth/daily-co2 (accessed August 18, 2017).

Walker, B., \& Salt, D. 2006. Resilience thinking: Sustaining ecosystems and people in a changing world. Washington: Island Press. 